УДК 330.322

JEL: $\mathrm{O31}$

DOI: http://doi.org/10.32750/2019-0109

\author{
Лойко Дар'я Миколаївна \\ кандидат економічних наук, доцент, \\ докторант кафедри теоретичної та прикладної економіки \\ Чернігівського національного технологічного університет, \\ м. Чернігів, Україна \\ ORCID ID: 0000-0002-2443-2719 \\ e-mail:loyko_d@i.ua
}

\title{
ІННОВАЦІї ЯК РУШІЙНА СИЛА СПОЖИВЧОГО СЕКТОРУ ЕКОНОМІКИ
}

\begin{abstract}
Анотація. Споживчий сектор економіки є неоднорідним за своїм складом і включає в себе як споживання промислових і непромислових товарів, так і споживання різних видів послуг. За результатами проведеного аналізу зроблено висновок про згортання екстенсивного розвитку споживчого сектору економіки України. Кількість прачівників, зайнятих на різних підприємствах споживчого сектору за останні сім років зменшилась на 21,42\%. Зростає важливість розвитку споживчого сектору економіки за рахунок інновачійних чинників. Останні десятиріччя характеризуються тенденцією до динамічних змін споживчих уподобань населення. Споживчий сектор можна вважати індикатором соціально-економічної ефективності інновачійної діяльності підприємств. Питома вага інновачійно активних вітчизняних промислових підприємств склала у 2018 р. 16,1\% від їх загальної кількості. Питома вага підприємств, що впроваджували інновації у 2018 р. склала 14,1 \% від загальної кількості підприємств і за період 2013-2018 рр. знизилась на $3,67 \%$. Низький рівень питомої ваги інновачійно активних підприємств є негативним чинником розвитку вітчизняної економіки. Активність українських новаторів за період 2014-2018 рр. зросла за кількістю поданих заявок на реєстрацію прав промислової власності на 24,09 \%. 3більшилася кількість заявок за напрямом «Інші споживчі товари» (+35,6 \% ). Зважаючи на пріоритетність витрат вітчизняних домогосподарств на продукти харчування та одяг і взуття доцільно стимулювати розвиток інновачій на підприємствах харчової та легкої промисловості. Темпи виробництва продукції у текстильному, швейному та шкіряному виробництвах України зростали в період 2014, 2016-2017 рр., і знижувалися у 2015 р. та 2018 р. Змінюються технології, які використовуються для виготовлення одягу. Використовуються иифрові технології віртуальних моделей одягу, технології 3D-друку моделей одягу і взуття. Це дозволяє задовільнити зростаючі вимоги споживацького попиту та економічно рачіонально використовувати матеріальні та трудові резерви виробничтва.
\end{abstract}

Ключові слова: Україна, економіка, споживчий сектор, проблеми, перспективи, інновачії, винахідницька активність, віртуальні технології, 3D-друк, розвиток.

๑ Д. М. Лойко, 2019

\section{ВСТУП}

Постановка проблеми. Споживчий сектор економіки є неоднорідним за своїм складом і включає в себе як споживання промислових і непромислових товарів, так і сектор споживчих послуг, які є дуже різними за складом та споживачами. До споживчого сектору від- носяться також підприємства різних видів діяльності, які забезпечують потреби споживачів у різних видах товарів та послуг. Обсяги споживання різних товарів та послуг, зокрема товарів першої необхідності, до яких відносяться продукти харчування та одяг, із року в рік зростають, тому споживчий сектор економіки значно 
впливає на національну економіку в цілому. Динамічність розвитку споживчого сектору економіки відбувається за рахунок взаємного впливу процесів виникнення та впровадження великої кількості інновацій.

Аналіз останніх досліджень і публікацій. Питання розвитку та впровадження інновацій розглядало багато вчених, зокрема: O.I. Амоша, Т.Є. Воронкова, М.П. Денисенко, С.А. Іляшенко, В.В. Лойко, А.Ю. Рамський, В.А. Ткаченко, Р.Б. Тян, Л.І. Федулова, Б.І. Холод та інші. Питання процесів забезпечення внутрішнього ринку товарів та послуг розглядались у працях небагатьох вчених, зокрема: Г.В. Козаченко, В.А. Босенко, А.В. Черних, Л.Г. Мельник, А.С. Капліна, I.О. Богатирьов, В.С. Пономаренко, О.I. Пушкар, М. Кизим, А. Капліна, Н. Мардус, О. Ралко, I. Тюха, О. Грабельська, Н. Мала та інші. Проте більш глибокого опрацювання потребують питання дослідження інновацій як рушійної сили споживчого сектору економіки.

Мета статті. Дослідження основних тенденцій та інноваційних змін у галузях споживчого сектору економіки, зокрема у легкій промисловості.

\section{РЕЗУЛЬТАТИ ДОСЛІДЖЕННЯ}

За проведеними дослідженнями кількість працівників, зайнятих у споживчому секторі економіки за період 2010-2017 рр., зменшилась на 21,42 \%, 3 них у фізичних осіб- підприємців зменшилась на 17,95 \% [1]. Це свідчить про те, що розвиток споживчого сектору за рахунок екстенсивних чинників уповільнюється. В теперішній час зростає важливість розвитку споживчого сектору економіки саме за рахунок інноваційних чинників. Необхідно зауважити, що останні десятиріччя характеризуються тенденцією до динамічних змін споживчих уподобань населення. Тому споживчий сектор можна вважати індикатором соціально-економічної ефективності інноваційної діяльності підприємств.

Аналіз динаміки інноваційної активності промислових підприємств України за період 2013-2018 рр. (табл. 1) дозволяє зробити наступні висновки.

За досліджуваний період питома вага підприємств, що займались інноваціями, зменшилась на 4,17 \%. Питома вага інноваційно активних вітчизняних промислових підприємств склала у 2018 р. 16,1\% від їх загальної кількості. Питома вага підприємств, що впроваджували інновації у 2018 р. склала 14,1 \% від загальної кількості підприємств і за період 2013-2018 pр. знизилась на 3,67 \%. Загальний обсяг інноваційних витрат у промисловість зменшився за досліджуваний період на 6,13\%. У складі інноваційних витрат значно зросла питома вага внутрішніх науково-дослідних робіт (на 62,84 \% за останні шість років) та придбання машин, обладнання та програмного забезпечення (на 9,03 \% за досліджуваний період). Відмічені тенденції зростання обсягів фінансування внутрішніх науково-дослідних робіт та придбання обладнання є позитивним чинником розвитку вітчизняних промислових підприємств. Проте низький рівень питомої ваги інноваційно активних підприємств $€$ негативним чинником розвитку вітчизняної економіки.

Процес набуття майнових прав на інтелектуальний продукт, який є основою інновацій, впровадження, використання, отримання прибутку від інновації докорінним чином відрізняється від матеріального типу власності. Немайнові права на об’єкт інтелектуальної власності, належать конкретній людини - автору. Майнові права на інтелектуальні продукти набуває суб’єкт прав інтелектуальної власності шляхом оформлення та подачі заявки в установленому порядку. Власник майнових прав на інтелектуальний продукт матиме захист своїх прав тільки на території тієї держави, де ці права отримано. В Україні юридичні та фізичні особи можуть стати власниками об'єкту інтелектуальної власності наступними шляхами: шляхом реєстрації майнових прав на інтелектуальну власність або згідно договорів розпорядження майновими правами [2].

Ефективне використання інновацій можливо за умови належного управління активами інноваційної сфери та залучення до створення інновацій широкого кола винахідників. Проведене дослідження динаміки винахідницької активності українських новаторів (табл. 2) дозволяє зробити наступні висновки.

Активність українських новаторів за період 2014-2018 рр. зросла за кількістю поданих заявок на реєстрацію прав промислової власності на 24,09 \%. Кількість поданих заявок на винаходи за досліджуваний період зменшилась на 17,64 \%, на корисні моделі також зменшилась на 2,78\%, проте на промислові зразки зросла на 14,19 \% та на знаки для товарів і послуг також зросла на 41,68 \%. Потрібно зауважити, що найбільша кількість заявок спрямована саме на реєстрацію прав на знаки для товарів і послуг і активність цього виду винахідницької діяльності зростає найбільш динамічними темпами.

Пріоритетні напрями винахідницької активності заявників за період 2014-2018 рр. наступні: «Лікарські препарати» належить 18,4 \% заявок, «Біотехнологія» - 11,6 \%, «Органічна 


\section{ДИНАМІКА ПОКАЗНИКІВ ІННОВАЦІЙНОЇ АКТИВНОСТІ \\ ПРОМИСЛОВИХ ПІДПРИЄМСТВ УКРАЇНИ ЗА 2013-2018 pp.}

\begin{tabular}{|c|c|c|c|c|c|c|c|}
\hline \multirow{2}{*}{ Назва показника } & \multicolumn{6}{|c|}{ Роки } & \multirow{2}{*}{$\begin{array}{c}\text { Відхилення } \\
\text { даних } \\
2018 \text { p. } \\
\text { від даних } \\
2013 \text { p., \% }\end{array}$} \\
\hline & 2013 & 2014 & 2015 & 2016 & 2017 & 2018 & \\
\hline $\begin{array}{l}\text { Кількість працівників, задіяних у ви- } \\
\text { конанні наукових досліджень і розро- } \\
\text { бок, осіб }\end{array}$ & 155386 & 136123 & 122504 & 97912 & 94274 & 88128 & $-43,28$ \\
\hline $\begin{array}{l}\text { Питома вага підприємств, що займа- } \\
\text { лись інноваціями, \% }\end{array}$ & 16,8 & 16,1 & 17,3 & 18,9 & 16,2 & 16,1 & $-4,17$ \\
\hline $\begin{array}{l}\text { Питома вага підприємств, що впровад- } \\
\text { жували інновації, \% }\end{array}$ & 13,6 & 12,1 & 15,2 & 16,6 & 14,3 & 14,1 & 3,67 \\
\hline $\begin{array}{l}\text { Загальна сума витрат на інноваційну } \\
\text { діяльність, млн. грн. }\end{array}$ & 9562,6 & 7695,9 & 13813,7 & 23229,5 & 9117,5 & 9230,1 & $-3,48$ \\
\hline $\begin{array}{l}\text { Впроваджено нових технологічних } \\
\text { процесів, кількість }\end{array}$ & 1576 & 1743 & 1217 & 3489 & 1831 & 1786 & 13,32 \\
\hline $\begin{array}{l}\text { Впроваджено у виробництво іннова- } \\
\text { ційних видів продукції, найменувань }\end{array}$ & 3138 & 3661 & 3136 & 4139 & 2387 & 2134 & $-31,99$ \\
\hline $\begin{array}{l}\text { Питома вага реалізованої інноваційної } \\
\text { продукції в обсязі промислової, \% }\end{array}$ & 3,3 & 2,5 & 1,4 & - & 0,7 & 0,6 & $-81,82$ \\
\hline $\begin{array}{l}\text { Загальний обсяг інноваційних витрат } \\
\text { у промисловості, млн. грн. }\end{array}$ & 9562,6 & 7695,9 & 13813,7 & 23229,5 & 9117,5 & 8976,3 & $-6,13$ \\
\hline $\begin{array}{l}\text { У тому числі: } \\
\text { — внутрішні науково-дослідні робо- } \\
\text { ти, \% }\end{array}$ & 13,7 & 15,87 & 13,28 & 8,88 & 21,29 & 22,31 & 62,84 \\
\hline $\begin{array}{l}\text { - зовнішні науково-дослідні робо- } \\
\text { ти, \% }\end{array}$ & 3,4 & 6,93 & 1,49 & 1,69 & 2,51 & 2,12 & $-37,64$ \\
\hline $\begin{array}{c}\text { - придбання машин, обладнання } \\
\text { та програмного забезпечення, \% }\end{array}$ & 58,0 & 66,47 & 80,65 & 85,36 & 64,73 & 63,24 & 9,03 \\
\hline $\begin{array}{ll}\text { - придбання } & \text { інших } \\
\text { знань, } \% & \end{array}$ & 0,9 & 0,6 & 0,6 & 0,3 & 0,2 & 0,2 & $-77,78$ \\
\hline - інші, \% & 24,0 & 10,12 & 3,97 & 3,77 & 11,27 & 12,13 & $-49,45$ \\
\hline
\end{tabular}

Примітки:

1 - офіційні дані за 2014-2018 рр. наведено без урахування тимчасово окупованої території Автономної Республіки Крим і м. Севастополя;

Джерело: складено автором за даними [1].

тонка хімія» - 9,9 \%, «Хімічна сировина» $8,0 \%$. Збільшилася кількість заявок за напрямами: «Інші споживчі товари» $(+35,6 \%$ ) та «Інші спеціальні машини» (+38,6 \%). Потрібно звернути увагу на зростання кількості заявок за напрямом «Інші споживчі товари». Найбільша кількість заявлених промислових зразків від національних заявників у 2018 р. належала до наступних класифікованих напрямів: «Інструменти та пристрої» (571 промисловий зразок);
«Дозвілля та освіта» (290); «Пакування» (226); «Реклама» (178); «Текстиль та аксесуари» (138); «Будівництво» (115); «Меблі та господарчі товари» (93) та «Транспорт» (70 зразків) [3]. За проведеним аналізом кількості поданих заявок на винаходи, корисні моделі та промислові зразки за напрямами діяльності можна зробити висновок, що кількість інновацій, які можна віднести до сектору споживчої економіки, із року в рік зростає. 


\section{ДИНАМІКА ПОКАЗНИКІВ ВИНАХІДНИЦЬКОЇ АКТИВНОСТІ УКРАЇНСЬКИХ НОВАТОРІВ ЗА ПЕРІОД 2014-2018 pp.}

\begin{tabular}{|c|c|c|c|c|c|c|}
\hline \multirow{2}{*}{ Об’єкти промислової власності } & \multicolumn{5}{|c|}{ Роки } & \multirow{2}{*}{$\begin{array}{c}\text { Відхилення даних } \\
2018 \text { р. від даних } \\
2014 \text { р., \% }\end{array}$} \\
\hline & 2014 & 2015 & 2016 & 2017 & 2018 & \\
\hline Усього надійшло заявок & 44146 & 47819 & 51559 & 53462 & 54784 & 24,09 \\
\hline $\begin{array}{l}\text { У тому числі: } \\
\text { - винаходи }\end{array}$ & 4814 & 4497 & 4093 & 4049 & 3965 & $-17,64$ \\
\hline - корисні моделі & 9384 & 8618 & 9559 & 9112 & 9123 & $-2,78$ \\
\hline - промислові зразки & 2664 & 2080 & 2302 & 2480 & 3042 & 14,19 \\
\hline - знаки для товарів і послуг, усього & 27280 & 32621 & 35605 & 37817 & 38651 & 41,68 \\
\hline $\begin{array}{l}\text { у тому числі: } \\
\quad \text { - за національною процедурою }\end{array}$ & 18796 & 24652 & 29600 & 30183 & 30899 & 64,39 \\
\hline - за Мадридською системою & 8484 & 7969 & 6005 & 7634 & 7752 & $-8,63$ \\
\hline
\end{tabular}

Джерело: складено автором за даними [3].

Серед національних заявників-юридичних осіб найбільш активними у 2018 р. були: Національний університет харчових технологій (95 заявок), Національний університет біоресурсів і природокористування України (42 заявки), Одеський державний медичний університет (33 заявки) та Ужгородський національний університет (32 заявки) [3]. Таким чином, можна констатувати, що пріоритетними напрямами створення інновацій $є$ напрями, які відносяться до споживчої сфери економіки.

За статистичними даними у 2018 р. в українських родинах сукупні споживчі витрати складали 93 \% від сукупних доходів [1]. На продукти харчування кожна українська родина витрачає більше, ніж 50\% сукупного доходу, на одяг та взуття до 6,0\% [4]. Зважаючи на пріоритетність витрат вітчизняних домогосподарств на продукти харчування та одяг і взуття доцільно стимулювати розвиток інновацій на підприємствах харчової та легкої промисловості. Для виробників одягу український ринок споживачів одягу є привабливим. Україна має значну чисельність населення (на 01.01.2018 р. - 42386,4 тис. осіб) [1] та чотири чітко розмежованих сезони, які потребують наявність у кожного споживача відповідного одягу. Домогосподарства України витратили у 2018 р. на одяг та взуття 5,3\% від сукупних споживчих витрат. Враховуючи, що сукупні витрати в середньому на місяць на одне українське домогосподарство склали 7139,4 грн., то на одяг і взуття кожна українська родина витратила в середньому 378,39 грн. Кількість домогосподарств України у 2017 р. склала 16428838 одиниць, сукупні витрати українців одяг і взуття склали 6216507 тис. грн. [4].

Традиційно Україна була лідером із виготовлення одягу, а саме найбільш трудомісткого у виготовленні - верхнього одягу. За останні роки обсяги виробництва швейних виробів зменшилися у декілька разів. Це обумовлено багатьма причинами, проте однією із вагомих $€$ зростання обсягів імпорту одягу із азіатських країн, що створює значну конкуренцію виробникам одягу за ціновим сегментом. Відсутність стабільної сировинної бази та скорочення виробництва тканин також негативно впливають на обсяги виробництва одягу вітчизняними виробниками. Відсутність підприємств, які виробляють техніку для оснащення швейних підприємств також має свій негативний вплив на своєчасне оновлення та впровадження нових технологічних ліній для виробництва одягу. Проте, аналіз динаміки індексів промислової продукції за видами діяльності показав нарощування темпів виробництва підприємствами легкої промисловості за останні два роки (табл. 3). 


\section{ІНДЕКСИ ПРОМИСЛОВОЇ ПРОДУКЦІЇ \\ ЗА ВИДАМИ ДІЯЛЬНОСТІ ЗА ПЕРІОД 2013-2018 pp., \%}

\begin{tabular}{|c|c|c|c|c|c|c|c|}
\hline \multirow{2}{*}{ Вид діяльності } & \multicolumn{6}{|c|}{ Роки } & \multirow{2}{*}{$\begin{array}{c}\text { Зміна } \\
2018 / \\
2013 \\
+-\end{array}$} \\
\hline & 2013 & 2014 & 2015 & 2016 & 2017 & 2018 & \\
\hline $\begin{array}{l}\text { Текстильне виробництво, виробни- } \\
\text { цтво шкіри, одягу зі шкіри та інших } \\
\text { матеріалів - всього }\end{array}$ & 94,1 & 98,6 & 92,0 & 102,2 & 107,2 & 96,8 & 2,7 \\
\hline Текстильне виробництво & 93,4 & 103,9 & 96,8 & 104,9 & 112,6 & 96,5 & 3,1 \\
\hline Виробництво одягу & 95,2 & 102,0 & 92,1 & 101,0 & 104,4 & 97,9 & 2,7 \\
\hline $\begin{array}{l}\text { Виробництво шкіри, виробів зі шкіри } \\
\text { та інших матеріалів }\end{array}$ & 92,7 & 84,0 & 84,5 & 101,5 & 107,0 & 94,1 & 1,4 \\
\hline
\end{tabular}

Джерело: складено автором за даними [1]

Відповідно до даних, наведених в табл. 3, можна констатувати, що темпи виробництва продукції у текстильному, швейному та шкіряному виробництвах зростали в період 2014, 2016-2017 рр., і знижувалися у 2015 р. та 2018 р.

Потрібно зауважити, що споживацькі уподобання щодо одягу почали змінюватися більш швидкими темпами, що вимагає від виробників значного пристосування під запити споживачів. Змінюється світ моди щорічно і у розвитку моди є свої закони. На неї впливає багато різних факторів: технології, переваги, клімат, платоспроможність споживачів, і навіть, їх бажання заощадити на окремих категоріях товарів, що відносяться до базових споживчих товарів. Представники заможного класу, рівень доходів яких значно вище середнього класу, надають перевагу товарам класу «люкс» і при формуванні ї смаків велике значення має індустрія кіно. Тому багато дизайнерів враховують при створенні своїх нових моделей одягу як сучасні матеріали так і дизайнерські образи, які пропонує кіноіндустрія. За прогнозами економістів, у наступні п'ять років витрати покупців на популярні речі у Франції збільшиться вдвічі: $323 \%$ до $40 \%$ [5]. Отже, має перспективи розвиток сегменту «високої моди» та товарів класу «люкс». Бажання людей володіти чимось надзвичайним навіть через 20 років залишається таким же, як зараз. На думку доктора Марка Саммера зі Школи дизайну Університету Лідса, «завдання моди - задовольняти психогенні потреби споживачів» [5]. Більш широке розповсюдження сучасних цифрових технологій сформувало новий напрям в індустрії моди - використання цифрових технологій і віртуальної реальності. Щоб приміряти вподобану річ, не обов'язково ï шити. Такі можливості використовуються в різних аспектах бізнесу, особливо в сфері адаптації продуктів і послуг до індивідуальних інтересів споживачів. Норвезький ритейлер «Carlings» вже у 2018 р. запустив цифрову колекцію: речі існували тільки на сайті, покупець міг ввести свої параметри і побачити на екрані комп'ютера фото себе, вдягненого саме у цю річ, щоб побачити, як саме буде виглядати одяг. Якщо річ покупцю сподобалась, то її відшивають спеціально для цього покупця за замовленими параметрами. Така технологія має свої переваги і недоліки. До переваг можна віднести те, що попереднє замовлення обраної з сайту моделі, гарантує покупку і значно економіть ресурси швейних підприємств. До недоліків можна віднести те, що віртуальна примірка уподобаної моделі одягу не гарантує $100 \%$ реального вигляду споживача у даній моделі і вимагає від швейних підприємств швидкого реагування на виконання індивідуальних замовлень, що потребує як високої кваліфікації робітників, так і наявності всіх матеріальних ресурсів, які закладено до електронного каталогу моделей одягу.

Сегмент моди класу люкс передбачає важливість розробки товарів і послуг, які відповідають вимогам і перевершують очікування споживачів, що можливо тільки в сфері індивідуальних замовлень на послуги виробничого характеру. Якщо споживачам не подобається одяг, який існує тільки онлайн, то світ моди пропонує інші інновації. Наприклад, ідеальні речі, спроектова- 
ні тільки для вас в залежності від необхідності. Це стосується індивідуальних замовлень речей, які спроектовані саме за уподобаннями окремого споживача і сконструйовано та надруковано за допомогою 3D-технологій. Індивідуалізація гарантує, що всі переваги і смаки будуть належним чином враховані і забезпечена можливість більшою мірою контролювати процес вибору придбаних товарів, що підвищує рівень задоволеності якістю послуг. Наприклад, сучасний споживач може надрукувати власні кросівки. Технологію 3D-друку вже використовують такі великі бренди, як Nike i Нуре. Покупець може завантажити модель кросівок і надрукувати їх на власному 3D-принтері. Крім того, покупцям часто пропонують самим вирішити в Instagram, який дизайн вибрати фірмі. 3 іншого боку, зворотний зв'язок зі споживачем дозволяє сегменту моди класу люкс використовувати цей ефект і застосувати його в дизайні одягу. На думку дизайнерів, світ рухається до індивідуальної моді, орієнтованої на споживача, тільки ще належить зробити індивідуалізацію ключовим аспектом корпоративних стратегій.

Змінюються технології, які використовуються для виготовлення одягу. Компанії виробляють «розумні» тканини, які можуть збирати й аналізувати дані. Кросівки Nike Adapt BB повідомляють своєму власникові, як уникнути травми під час гри в баскетбол. В даний час лише окремі світові люксові бренди пропонують товари, виготовлені за індивідуальними замовленнями, і ексклюзивні індивідуальні послуги для невеликого числа обраних клієнтів, що робить цей сегмент перспективним для вітчизняних будинків мод і ательє розряду люкс, вищого розряду. 3 запуском інтернету $5 \mathrm{G}$ одяг стане новим гаджетом, який буде дозволяти спілкуватися з іншими. Моделі одягу, створені за допомогою сучасних інноваційних технологій коштують дорого, тому виникає питання, чи будуть ці моделі загальнодоступними чи залишаться перевагою окремого прошарку населення. Один із способів залучення платоспроможних клієнтів - це створення унікальних виробів, що відрізняються від типових наявністю поліпшуючих та радикальних інновацій. Масові бренди втрачають свою популярність, натомість люди все частіше віддають перевагу індивідуальним речам та речам, створеним вручну. Одноосібне володіння - це вже обов'язкова умова для сучасної людини. 3 появою нових, інноваційних технологій виробництва відбувся перехід на використання у виробництві машин, що дозволило, з одного боку, виготовляти більше товарів з меншими витратами і робити це без шкоди характеристикам продукту і його стилю, з іншого - призвело до стандартизації та однаковості вироблених товарів. Багато фірм, розробляючи стратегічні плани розвитку, замислюються, чи варто робити ставку на моделі одягу, створені за інноваційними технологіями, чи варто залишатися у сегменті виробництва більш масових моделей одягу.

Спостерігається світова тенденція у споживанні, що із зростанням рівня доходів, споживачі надають перевагу індивідуальним замовленням у всіх сферах свого життя [6]. Тому зростає потреба у застосуванні сучасних i, навіть, надсучасних технологій у споживчому секторі економіки.

\section{ВИСНОВКИ ТА ПЕРСПЕКТИВИ ПОДАЛЬШИХ ДОСЛІДЖЕНЬ}

На основі проведених досліджень можна сформувати перспективні напрями, на яких доцільно зосередити зусилля новаторів у вітчизняному споживчому секторі економіки:

- покращення якості товарів споживання першої необхідності, а саме, продуктів харчування, одягу та взуття;

- впровадження інновацій на підприємствах харчової та легкої промисловості, як основи формування динамічних змін у споживчому секторі економіки країни;

- забезпечення населення якісними товарами споживання на основі розробки та впровадження різних інновацій;

- покращення умов проживання населення, а саме, інноваційні трансформації житлово-комунальної інфраструктури всіх населених пунктів України;

- підвищення якості надання освітніх, медичних, побутових та інших споживчих послуг населенню.

У наукових працях економістів наголошується про необхідність надавати пріоритетну перевагу суспільним послугам під час планування місцевих бюджетів, що сприятиме підвищенню рівнів соціальної захищеності населення та соціальної безпеки держави. Якісні зміни у проведені економічних реформ в Україні можуть призупинити економічний спад та поступово відновити економічне зростання, що сприятиме розвитку та оновленню на основі інновацій споживчого сектора економіки. 


\title{
СПИСОК ВИКОРИСТАНИХ ДЖЕРЕЛ
}

1. Офіційний сайт Державної служби статистики України. Статистична інформація. URL: www.ukrstat.gov.ua. (дата звернення 5.05.2019).

2. Loiko V., Ramskyi A. Problems and perspectives of creation and commercialization of intellectual products in higher educational establishments. Periodic Naukowy Akademii Polonijnej. 2018. № 3 (28). C. 62-67.

3. Промислова власність у цифрах. Показники діяльності Міністерства економічного розвитку і торгівлі та Державного підприємства «Український інститут інтелектуальної власності» за 2018 р. URL: https://ukrpatent.org.ua/i_upload/file/promvlasnist-2018.pdf. (дата звернення 3.05.2019).

4. Лойко Д.М. Динаміка змін у структурі споживання домогосподарств України. Міжнародний науковий журнал «Інтернаука». Серія: Економічні науки. 2018. № 7. С. 107-112.

5. Виртуальное платье или брюки на прокат: какой будет мода через 20 лет? URL: https://etcetera.media/ virtualnoe-plate-i-bryuki-naprokat-kakoy-budet-moda-cherez-20-let.html?utm_source=iua1 (дата звернення 3.05.2019).

6. Лойко Д.М. Характеристика споживчого сектору економіки як соціально-економічної системи. Інфраструктура ринку. 2018. Вип. 22. С. 43-47. URL: http://www.market-infr.od.ua/journals/ 2018/22_2018_ukr/22_2018.pdf

\author{
Лойко Дарья Николаевна \\ кандидат экономических наук, доцент, \\ докторант кафедры теоретической и прикладной экономики, \\ Черниговского начионального технологического университета, \\ 2. Чернигов, Украина \\ ORCID ID: 0000-0002-2443-2719 \\ e-mail: loyko_d@i.ua
}

\section{ИННОВАЦИИ КАК ДВИЖУЩАЯ СИЛА ПОТРЕБИТЕЛЬСКОГО СЕКТОРА ЭКОНОМИКИ}

Аннотация. Потребительский сектор экономики является неоднородным по своему складу и включает в себя как потребление промышленных и непромышленных товаров, так и потребление различных видов услуг. По результатам проведенного анализа сделано вывод про сворачивание экстенсивного развития потребительского сектора экономики Украины. Количество работников, занятых на различных предприятиях потребительского сектора экономики за последние семь лет сократилось на 21,42\%. Увеличивается значимость развития потребительского сектора за счет инновачионных факторов. Последние десятилетия характеризуются тенденцию до динамических изменений потребительских предпочтений населения. Потребительский сектор можно считать индикатором сочиально=экономической эффрективности инновационной деятельности предприятий. Удельный вес инновационно активных промышленных предприятий составил в 2018 2. 16,1% от общего их количества. Удельный вес предприятий, которые внедряли инновации в 2018 г. составил $14,1 \%$ от общего количества предприятий и за период 2013-2018 г2. снизился на 3,67 \%. Низкий уровень удельного веса инновационно активных предприятий является негативным фрактором развития отечественной экономики. Активность украинских новаторов за период 2014-2018 г2. возросла по количеству поданных заявок на регистрацию прав промышленной собственности на 24,09\%. Увеличилось количество заявок по направлению «Другие потребительские товары» (+35,6\%). Учитывая приоритетность затрат отечественных домохозяйств на продукты питания, одежду и обувь целесообразно стимулировать развитие инновачий на предприятиях пищевой и легкой промышленности. Темпы производства продукции в текстильном, швейном и кожевенном производствах Украины возрастали в период 2014, 2016-2017 г2., и снижались в 2015 г. и 2018 г. Изменяются технологии, которые используются для изготовления одежды. Используются цифровые технологии виртуальных моделей одежды, технологии 3D-печати моделей одежды и обуви. Это позволило удовлетворить возрастающие требования потребительского спроса и экономически рачионально использовать материальные и трудовые ресурсы производства.

Ключевые слова: Украина, экономика, потребительский сектор, проблемы, перспективы, инновачии, изобретательская деятельность, виртуальные технологии, 3D-печать, развитие. 


\section{Daria Loiko}

Ph.D. (Economics), Associate Professor,

doctoral student, Chernihiv National University of Technology

Chernihiv, Ukraine

ORCID ID: 0000-0002-2443-2719

e-mail: loyko_d@i.ua

\section{INNOVATIONS AS A DRIVING FORCE OF THE CONSUMER SECTOR OF THE ECONOMY}

Abstract. The consumer sector of the economy is heterogeneous in its composition and includes consumption of industrial as well as non-industrial goods and also consumption of various types of services. According to the results of our analysis, the conclusion is drawn about the collapse of extensive consumer sector development in the Ukrainian economy. Over the last seven years the number of employees working at various enterprises of the consumer sector has decreased by $21.42 \%$.

The importance of developing the consumer sector of the economy due to innovative factors is growing. The last decades are characterized by a tendency towards dynamic changes in consumer preferences of the population. The consumer sector can be considered as an indicator of the socio-economic efficiency of innovation activity of enterprises. The share of domestic industrial enterprises actively introducing innovations in 2018 was $16.1 \%$ of their total number. The share of enterprises that introduced innovations in 2018 amounted to $14.1 \%$ of the total number of enterprises and for the period 2013-2018 it decreased by $3.67 \%$. The low level of the share of enterprises widely implementing innovations in their production process is a negative factor in the development of the domestic economy.

The activity of Ukrainian innovators in the period from 2014 to2018 has grown by the number of submitted applications for the registration of industrial property rights by $24.09 \%$. The number of applications for the item «Other consumer goods» has also increased (+35.6\%). Given the priority of domestic households\&apos; spending on food, clothing and footwear, it is expedient to stimulate the development of innovations in the enterprises of food and light industry.

The rates of production in the textile, clothing and leather industries of Ukraine increased in 2014 and also in the period from 2016 to 2017, and decreased in 2015 and 2018. The technologies used for manufacturing clothes are changing. Digital technologies of virtual clothing models as well as 3D printing technologies for making clothes and footwear are widely introduced. It allows to satisfy the growing consumer demand and to efficiently use the material and labour reserves of production.

Keywords: Ukraine, economy, consumer sector, problems, prospects, innovations, inventive activity, virtual technologies, 3D-printing, development.

\section{REFERENCES}

1. Statistical information. Official site of the State Statistics Service of Ukraine. (n.d.). Retrieved May 5, 2019, from www.ukrstat.gov.ua.

2. Loiko, V., \& Ramskyi, A. (2018). Problems and perspectives of creation and commercialization of intellectual products in higher educational establishments. Periodic Naukowy Akademii Polonijnej, 3(28), 62-67. doi: https://doi.org/10.23856/2807

3. Industrial property in numbers. Performance of the Ministry of Economic Development and Trade and the State Enterprise «Ukrainian Institute of Intellectual Property». (n.d.). Retrieved March 3, 2019, from https://ukrpatent.org.ua/i_upload/file/promvlasnist-2018.pdf.

4. Loiko, V. (2018). Dynamics of changes in the structure of household consumption in Ukraine. Mizhnarodnyi Naukovyi Zhurnal «Internauka». Seriia Ekonomichni Nauky., 7, 107-112.

5. Virtual dress or pants for hire: what will be the fashion in 20 years? (n.d.). Retrieved February 16, 2019, from https://etcetera.media/virtualnoe-plate-i-bryuki-naprokat-kakoy-budet-moda-cherez-20-let.html?utm source $=$ iual

6. Loiko, D. (2018). Characteristics of the consumer sector of the economy as a socio-economic system. Infrastruktura Rynku., 22, 43-47. Retrieved from http://www.market- infr.od.ua/journals/2018/22_2018_ ukr/22_2018.pdf 